American Journal of Applied Sciences 7 (2): 265-269, 2010

ISSN 1546-9239

(C) 2010 Science Publications

\title{
Emerging Stock Market Performance and Economic Growth
}

\author{
Seyyed Ali Paytakhti Oskooe \\ School of Economics, Kingston University, \\ Kt1 2EE, Kingston upon Thames, London, United Kingdom
}

\begin{abstract}
Problem statement: In spite of significant development in Iran stock market as a emerging stock market, there has been not specific research on the causality between the stock prices and economic growth. This study represented a systematic investigation of the relationship between stock market performance and economic growth in Iran by conducting causality tests within the Vector Error Correction Model (VECM) framework. Approach: To achieve this objective unit root tests are fulfilled for all time series data in their levels and their first differences. Johansen co-integration analysis is used to investigate whether the variables are co-integrated of the same order taking into account the maximum eigenvalues and trace statistics tests. A vector error correction model is applied to examine the long-run relationship between stock market performance and economic growth. Finally, Granger causality test is applied in order to find the direction of causality between the examined variables of the estimated model. Results: Findings imply the causality link between economic growth and stock price fluctuations in the long run, as well as bilateral causality running between share prices and economic growth in the short run. Conclusion: Therefore, it can be inferred that the level of real economic activity is the main factor in the movement of stock prices in the long run and stock market plays a role as a leading economic indicator of future economic growth in Iran in the short run.
\end{abstract}

Key words: Stock market development, causality test, economic growth

\section{INTRODUCTION}

The role of stock market as part of financial markets in economic development process is emphasized by growth theories. The interaction between stock prices movements and real economic activities has been a debated issue in majority of economic studies. In this connection, two crucial questions have become the main focus of attention. First, are stock prices or share price movements influenced by economic change or are they determined on the basis of speculative bubbles? Second, to what extent does the stock market performance as a macroeconomic indicator affect the prospects for economic growth?

There are a lot of studies about the connection between stock prices fluctuations and economic growth as well as other economic variables which have detected that changes in stock prices reflect real economic situation. Economic growth through the changes in levels of real economic activities affects profitability and activity of firms. As a result, with changes in profitability prospects, expected earnings and dividends of shares, stock prices fluctuate (Fama, 1990; Ferson and Harvey, 1993; Cheung and Ng, 1998; Mauro, 2003; Ritter, 2005; Liu and Sinclair, 2008; Shahbaz et al., 2008).
On the other hand, other studies have examined the impact of stock prices on macroeconomics indicators. According to the results of these investigations share prices fluctuations play a role in directing economic activities in the medium and long term. Stock prices reflect the expectation of public towards the future economic activity. In other words, the stock market is forward-looking and stock prices reflect anticipations about future economic activity. If a recession is expected, for example, then stock prices reflect this by decreasing in value whereas large increase in stock prices may reflect the expectation towards future economic growth (Jefferis and Okeahalam, 2000; Nasseh and Strauss, 2000; Mauro, 2000; Shirai, 2004; Adajaski and Biekpe, 2005; Mun et al., 2008).

In the light of the mixed empirical results in the literature, we are motivated to examine the empirical support for the causality link between stock price fluctuations and economic growth in a developing country, in particular Iran, as opposed to the advanced industrialized countries. In spite of significant development in Iran stock market in recent years, there has been not specific research on the causality between the stock prices movements and economic growth performance. The aim of this study is to investigate the short run dynamics and long term equilibrium 
relationship between changes of real GDP as an economic growth indicator and stock prices fluctuations for the emerging Iran stock market.

There are several reasons why investigating the causality between stock market and economic growth in Iran is particularly important. First, the study can provide evidence as to whether theories relevant to role of stock market in economic growth and the findings from developed and developing countries can be applied to Iran economy. Second, from a policy point of view, analyzing the relationship between stock market performance and economic growth is important in designing economic development programmes.

This study has two objectives:

- $\quad$ To examine the long run relationship among stock market performance and economic growth in Iran

- To apply granger causality test based on a vector error correction model in order to examine the causal relationships between the stock prices and GDP growth taking into account Johansen cointegration analysis

The remainder of this study is organized as follows: Initially the data and the specification of the multivariate VAR model are described. After that stationarity test and Johansen co-integration analysis are fulfilled taking into account the estimation of vector error correction model. On the other hand, Granger causality test is applied in order to find the direction of causality between the examined variables of the estimated model. Then the empirical results and some discussion issues are presented. Finally the conclusions are summarized relatively.

\section{MATERIALS AND METHODS}

Data and specification model: When the time series are nonstationary and cointegrated, the causality test can be performed according to the following equations:

$$
\begin{aligned}
\left(\begin{array}{l}
\Delta \mathrm{X}_{\mathrm{t}} \\
\Delta \mathrm{Y}_{\mathrm{t}}
\end{array}\right)= & \left(\begin{array}{l}
\mathrm{a}_{1} \\
\mathrm{a}_{2}
\end{array}\right)+\left(\begin{array}{ll}
\mathrm{A}_{11}(\mathrm{~L}) & \mathrm{A}_{12}(\mathrm{~L}) \\
\mathrm{A}_{21}(\mathrm{~L}) & \mathrm{A}_{22}(\mathrm{~L})
\end{array}\right)+\left(\begin{array}{l}
\Delta \mathrm{X}_{\mathrm{t}-1} \\
\Delta \mathrm{Y}_{\mathrm{t}-1}
\end{array}\right)+ \\
& \left(\begin{array}{l}
\mathrm{a}_{\mathrm{x}} \mathrm{u}_{\mathrm{t}-1} \\
\mathrm{a}_{\mathrm{y}} \mathrm{u}_{\mathrm{t}-1}
\end{array}\right)+\left(\begin{array}{l}
\mathrm{e}_{\mathrm{xt}} \\
\mathrm{e}_{\mathrm{yt}}
\end{array}\right)
\end{aligned}
$$

Where:

(L) $=$ A lag operator

$\mathrm{u}_{\mathrm{t}}=$ The residual term from the long-run equilibrium relation such as:

$$
\mathrm{X}_{\mathrm{t}}=\beta_{1} \mathrm{y}_{\mathrm{t}}+\mathrm{u}_{\mathrm{t}}, \quad \mathrm{u}_{\mathrm{t}} \sim\left(0, \sigma^{2}\right)
$$

The Error-Correction (EC) coefficients $a_{i}(i=1,2)$ capture the adjustments process towards long-run equilibrium, while the $\operatorname{Aij}(\mathrm{i}, \mathrm{j}=1,2)$ reflect the shortrun dynamics of the model. The formulation of Eq. 1 provides investigation of the causal relationship between variables both in the short run and long run.

The data analyzed in this study consists of economic and financial time series of Iran there are real Gross Domestic Product (GDP) and Iran stock market index (BPI).Quarterly GDP at constant prices and stock Price Indices (BPI) for Iran are taken from the Central Bank of Iran and Iran stock market web sites. The data set of the study consists of 45 observations covering the period from 1997:3-2008:3.

The graphs of quarterly Iran stock prices index (Fig. 1) offer visual support for the possibility of a break in trend behavior around 2005:Q1, when the political challenge about Iranian nuclear programme started. Following these reasons, the two dummy variables for a break in the level (or intercept) and break in the slope (or the rate of growth) are considered.

When data are collected quarterly, the data are very likely to be seasonal. Figure 2 shows the existence of seasonality in Iran GDP data trend. Therefore, the moving average methods are applied to remove seasonality from the GDP series. Therefore, the seasonally adjusting series are used in econometrics analysis.

Unit root test: The variables used in this study are used in the logarithms form, so that the first differences of GDP and stock prices represent the economic growth rate and changes in stock prices, respectively. The results from ADF tests are summarized in Table 1. The lag length is chosen by downward search and the $t$ statistics reported are from the longest significant lag. The null hypothesis of a unit root is not rejected for any of the two variables. However, each of the series is stationary in first differences, so all the variables are integrated of order one (I (1)).

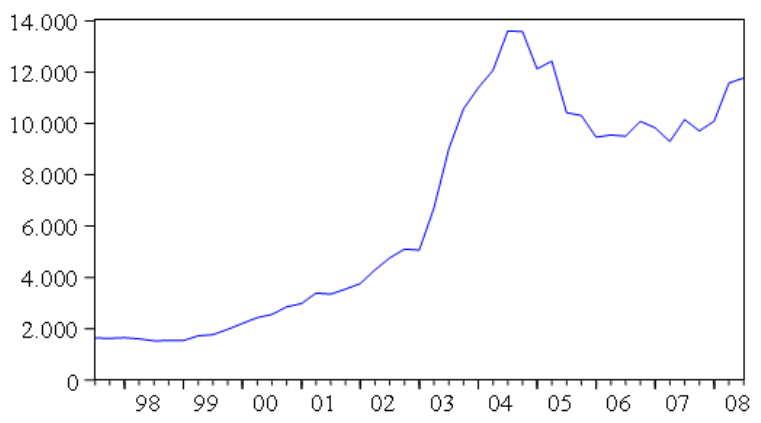

Fig. 1: Time plot of quartely Iran stock market index 
Am. J. Applied Sci., 7 (2): 265-269, 2010

Table 1: The unit root test

\begin{tabular}{lll}
\hline Variables & ADF at level & ADF at first difference \\
\hline LGDP & $0.018532(1)$ & $-9.423447 * * *$ \\
LBPI & $-1.108720(1)$ & $-4.287041^{* *}$ \\
\hline
\end{tabular}

Note: $* *$ and $* * *$ : Denote significance at the 5 and $1 \%$ levels, respectively; Figures in parentheses are the number of lags used

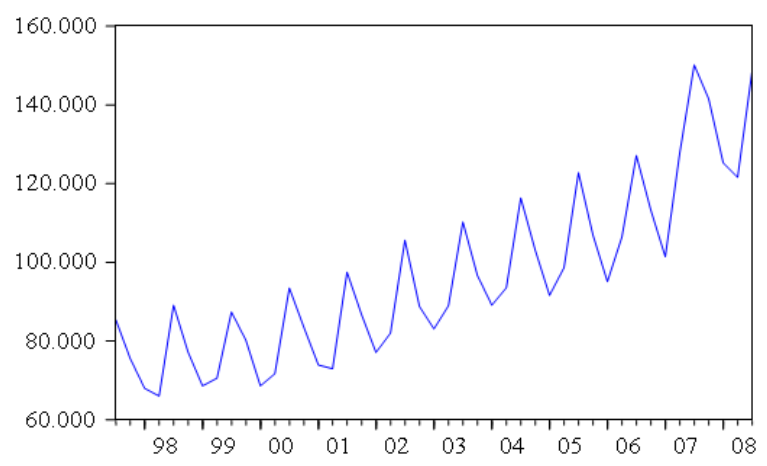

Fig. 2: Time plot of quartely Iran GDP

Testing for cointegration: For testing cointegrating relationships, the general to specific approach is taken to search for a suitable lag length. The selection criterion is a combination of Akaike's information criteria and diagnostic tests. A model with two lags, a constant and dummies constrained to lie in the cointegration space is chosen. The number of cointegration vectors is tested by applying the maximum likelihood based on $\lambda_{\max }$ and $\lambda_{\text {trace }}$ statistics introduced by Johansen and Juselious (1990).

Testing for causality: According to the Granger (1969) causality approach, a variable for example real GDP, is caused by BPI (stock prices index) if GDP can predicted better from past values of GDP and BPI than from past values of GDP alone. For a simple bivariate model, we can test the causality between stock market growth and economic growth.

\section{RESULTS AND DISCUSSION}

The results from cointegrating tests for the VAR system presented in Table 2 indicate that there is one cointegration vector. Applying VECM approach after normalizing the coefficients of stock price indices to one, the cointegrating relationship between stock prices and GDP for Iran can be expressed as:

$$
\text { LBPI }=\mathrm{C}+6.8537 \text { LGDP }+ \text { Dum }
$$

Equation 3 indicates that the long-run level of stock prices is positively affected by the level of real GDP.
Table 2: Johansen cointegration test

\begin{tabular}{lllll}
\hline Null & $\lambda_{\max }$ & $95 \% \mathrm{CV}$ & Trace test & $95 \% \mathrm{CV}$ \\
\hline $\mathrm{r}=0$ & 14.2287 & 14.8800 & 16.8815 & 17.8600 \\
$\mathrm{r}=1$ & $2.6528^{* *}$ & 8.0700 & $2.6528^{* *}$ & 8.0700 \\
\hline
\end{tabular}

Note: **: Denotes significance at the $5 \%$ level

Table 3: Causality test

\begin{tabular}{llll}
\hline & Independent variable & \\
Dependent & - & LBPI & Inference \\
variable & LGDP & LBP & BPI $\rightarrow$ GDP \\
LGDP & $9.5783^{* * *}$ & $11.8434^{* * *}$ & GDP $\rightarrow$ BPI \\
LBPI & $(0.003)$ & $(0.008)$ & \\
\hline Note: $* * *$ : Denotes significance at the $1 \%$ level &
\end{tabular}

This means that the changes in real GDP is significant in predicting movements in stock prices and stock price changes is basically connected to real economic activities in the long run in Iranian economy. The possible reason is that an increase in GDP raises expected future cash flow, firm's economic opportunities, corporate profitability and thereby, stock prices increase. The result is consistent with the findings from previous researches in the cases of $\mathrm{EU}$ and emerging economies (Wongbangpo and Sharma, 2002; Vazakidis and Adamopoulos, 2009).

Regarding to empirical results which presented in Table 3, the null hypothesis that the stock prices do not Granger cause economic growth is rejected at the 1\% significance level and confirm the existence of causal link running from stock price movements to economic growth in the short run. In the meantime, the null hypothesis that the economic growth does not Granger cause stock prices is b at the $5 \%$ significance level. As a result bilateral causality relationship between stock price fluctuations and economic growth in Iranian economy is confirmed.

The causal link from GDP growth to stock prices movements persists on the role of improving of economic activities in development of stock market. The causal link from stock prices to GDP growth implies that stock prices, which are generally the discounted present value of future dividends, can be used to anticipate future economic growth. The study's finding confirms the notion that the forward-looking nature of stock prices performs as a leading indicator of economic growth in Iranian economy.

Another possible explanation for why stock prices "Granger cause" economic activity is the wealth effect. According to this concept, fluctuations in stock prices through the change in wealth level, give rise to change in aggregate consumption and aggregate demand. As a result, economic activities level is affected by fluctuations in the stock market. 
Hence, from economic policymaking view, it can be noted that Iran government should improve the stock market in order to promote economic growth regarding to the fact that stock market performs as a leading indicator for economic growth. Furthermore, Iran government should consider development programme of the Iran stock market based on economic growth policies and development of economic activities. In spite of the dominating role of oil section in Iranian economy, the findings from this study emphasis on the role of stock market fluctuations in directing of economic activities in developing countries. In other words, our finding that changes in GDP are "Grangercaused" by changes in stock prices is important in that it provides additional support for the leading economic role of the stock market in Iranian economy.

\section{CONCLUSION}

This study empirically investigates the causal links between stock prices and economic growth in Iran within the VECM framework. The results from the Johansen cointegration test indicate that stock price movements are influenced by the level of real economic activities in the long run in Iran. In other words, economic growth is important in expectations and decisions of investors in stock market.

On the other hand, causal relationship exists between stock price movements and economic growth in the short run, indicating that the stock markets act as a leading indicator of economic growth. This finding is consistent with conclusion of other studies as discussed earlier. At the same time, there is a reversal effect from GDP growth to stock prices, implying that economic growth plays crucial role in affecting the Iran stock prices in the short run. In other words, movements in stock prices are determined by economic growth or economic fundamentals.

\section{REFERENCES}

Adajaski, C.K.D. and N.B. Biekpe, 2005. Stock market development and economic growth: The case of selected African countries. Afr. Dev. Rev., 18: 144-161.

http://www3.interscience.wiley.com/journal/11856 5413/abstract

Cheung, Y. and L.K. Ng, 1998. International evidence on the stock market and aggregate economic activity. J. Emp. Finance, 5: 281-96. http://www.elsevier.com/wps/find/journaldescripti on.cws_home/523106/description\#description
Fama, E.F., 1990. Stock returns, expected returns and real activity. J. Finance, XLV: 1089-1108. http://www.afajof.org/journal/browse.asp

Ferson, W.E. and C.R. Harvey, 1993. The risk and predictability of international equity returns. Rev. Fin. $\quad$ Stud., 6: 527-66. http://econpapers.repec.org/article/ouprfinst/default 6.htm

Granger, C.W.J., 1969. Investigating causal relations by econometric models and cross spectral methods. Econometrica, 37: 424-438. $\mathrm{http} / / /$ econpapers.repec.org/article/ecmemetrp/defa ult37.htm

Jefferis, K.R. and C.C. Okeahalam, 2000. The impact of economic fundamentals on stock markets in Southern Africa. Dev. South. Afr., 17: 23-51. http://www.informaworld.com/smpp/title $\sim \mathrm{db}=\mathrm{all} \sim \mathrm{c}$ ontent $=\mathrm{g} 713413759$

Johansen, S. and K. Juselious, 1990. Maximum likelihood estimation and inference on cointegrated with applications to the demand for the money. Oxford Bull. Econ. Stat., 52: 169-210. http://time.dufe.edu.cn/wencong/jjwx/mleic.pdf

Liu, X. and P. Sinclair, 2008. Does the linkage between stock market performance and economic growth vary across Greater China? Applied Econ. Let., 15: 505-508.

http://www.tandf.co.uk/journals/offer/raec-so3.asp

Mauro, P., 2000. Stock returns and output growth in emerging and advanced economies. http://www.imf.org/external/pubs/ft/wp/2000/wp00 89.pdf

Mauro, P., 2003. Stock market returns and output growth in emerging and advanced economies. J. Dev. $\quad$ Econ., 71: 129-153. http://www.elsevier.com/wps/find/journaldescripti on.cws_home $/ 505546 /$ description\#description

Mun, H.W., E.C. Siong and B.S. Long, 2008. Stock market and economic growth in Malaysia: Causality test. Asi. Soc. Sci., 4: 86-92. http://www.ccsenet.org/journal/index.php/ass/articl e/view/1605

Nasseh, A. and J. Strauss, 2000. Stock prices and domestic and international macroeconomic activity: A cointegration approach. Q. Rev. Econ. Finance, $\quad 40$ : 229-45. http://vnweb.hwwilsonweb.com/hww/Journals/getI ssues.jhtml? sid=HWW:OMNIS\&id $=01020$

Ritter, J.R., 2005. Economic growth and equity return. Pacif.-Basin Finance J., 13: 489-503. 
Shahbaz, M., N. Ahmed and L. Ali, 2008. Stock market development and economic growth: ARDL causality in Pakistan. Int. Res. J. Fin. Econ., 14: 182-195.

http://www.eurojournals.com/irjfe\%2014\%20shah baz.pdf

Shirai, S., 2004. Testing the three roles of equity markets in developing countries: the case of China. World Dev., 32: 1467-1486. http://econpapers.repec.org/article/eeewdevel/v_3a 32_3ay_3a2004_3ai_3a9_3ap_3a1467-1486.htm
Vazakidis, A. and A. Adamopoulos, 2009. Stock market development and economic growth. Am. J. Applied Sci., 6: 1933-1941. http://www.scipub.org/fulltext/ajas/ajas61119331941.pdf

Wongbangpo, P. and S. Sharma, 2002. Stock market and macroeconomic fundamental dynamic interactions: ASEAN-5 countries. J. Asi. Econ., 13: 27-51.

http://econpapers.repec.org/article/eeeasieco/v_3a1 3_3ay_3a2002_3ai_3a1_3ap_3a27-51.htm 